\title{
Development of Mobile Learning-based Edugame on Respiratory System Material to Improve Students' Digital Literacy
}

\author{
Ferlina Kale, Risya Pramana Situmorang ${ }^{*}$, Susanti Pudji Hastuti \\ Biology Education Department, Faculty of Biology, Universitas Kristen Satya Wacana, \\ Indonesia
}

Received: March 23, 2020

Revised: September 12, 2020

Accepted: September 13, 2021

\begin{abstract}
The purpose of this study aims to develop a mobile learning based Edugame in the aspects of product feasibility and test the effectiveness in improving students' digital literacy. The instruments were tests, questionnaires, and observation sheets. The research subjects were XI graders of Senior High School at Salatiga, Indonesia. This research was carried out through two phases, namely the first phase of developing mobile learning-based Edugame using the ADDIE model and the second phase testing the mobile learning-based Edugame developed to analyze its effectiveness. From the results of the trial find: 1) the developed mobile learning-based edugame considered valid with an average value of $82.24 \%$ (content expert) good category and 84.02 (media expert) good category, 2) the practicality of mobile learning based edugame from student response questionnaires with a value of $81.25 \%$ as good category, 3) the effectiveness of mobile learning based Edugame in terms of digital literacy completeness, reaching 3.42 very good category.
\end{abstract}

Keywords: Mobile learning, Edugame, digital literacy

(*) Corresponding Author: $\quad$ pramana.risya@staff.uksw.edu

How to Cite: Kale, F., Situmorang, R.P., \& Hastuti, S.P. (2021). Development of mobile learning-based edugame on respiratory system material to improve students' digital literacy. Formatif: Jurnal Ilmiah Pendidikan MIPA, 11 (2): 151-160. http://dx.doi.org/10.30998/formatif.v11i2.6237

\section{INTRODUCTION}

Biology is a branch of science that discuss life and its interactions with nature. Biological objects include the physiological work of the body including the respiratory system in humans. The respiratory system is a mechanism of action of organs that drain oxygen and exchange it with carbon dioxide to support the work of cells and tissues throughout the body. In a learning context, students are required to be able to identify and analyze various organs involved in the respiratory process and the mechanism of work of these respiratory organs (Lailiyah, 2018).

Understanding the concept of the respiratory organ requires comprehensive experimentation involving a contextual learning process. However, this activity also has limitation to see the breathing process directly and comprehensively. Indeed, it requires a students' skills to be able to identify important objects to observe. The experimental aspect is certainly important for students' skills, but reinforcement of student understanding is also essential to support the skills possessed (Ramansyah, 2015).

Strengthening students' understanding of the biological concept can be supported by utilizing technology. The use of technology in the design of instructional media is needed to facilitate students to be able to have skills and creativity through the process of using these learning media (Shroff et al., 2019). Technology in learning is used as an intermediary to convey material concretely and is easy to understand (Kutluca, 2010). Learning media 
cannot be separated from the learning process because learning media play an important role in channeling messages and information from learning resources to students (Eliana, Senam et al., 2016).

Learning media can be arranged in various types, one of which is edugame. Edugame is one of the learning media that can be used by teachers in the learning process and has the potential to increase student interest in learning (Dwiyono, 2017). It can encourage students to learn actively and creatively through several challenges given (Taufiq et al., 2014). Features on Edugame not only create an interesting learning atmosphere; but also, they can display varied materials and support challenging games to evaluate student understanding.

Edugame is designed using Adobe Flash CS 6 software to build interactive media accompanied by varied learning features. One feature that can be utilized is animation. Animation is a feature that provides the effect of images capable of moving so that they can dynamically present the object visualization process. Besides, Adobe Flash CS 6 can also synchronize with a smartphone so that it can be more practical in its use.

Mobile learning using smartphones is expected to encourage learning so that students can use and utilize technology at the same time (Ljungkvist \& Mozelius, 2012; Talan, 2020; Zhang \& Zuo, 2019). The characteristics of mobile learning include: portability (mobile devices can be brought to different locations), fast connectivity (mobile devices can be used to access various information anytime and anywhere), context sensitivity (mobile devices can be used to find and collect real data or simulations) (Ibrahim \& Ishartiwi, 2017).

The ability of the 21 st century is a skill that expects each generation be able to have life skills. One of the life skills that the current generation must have is digital literacy skills (Asrizal et al., 2018). Hague \& Payton (2010) states that the younger generation can access all digital media, but it has not been matched by the ability to use digital media as a development for themselves. Though not all the material presented in digital media is supported by relevant information, validity needs to be ascertained.

Some digital media are growing very rapidly in Indonesia at approximately 43,400 and the problem is the number registered with the Press Council is only around 243 (Prasetyo \& Djauhar, 2017). As a result, it can be very easy for the society to access various information, without being able to ensure the right information. The public will be easy to believe it, which cannot be assured. And this is an initial condition that there was much information very easy to be accepted or trusted upon the lowest literacy competence.

The existence of information must be verified properly through the empowerment of digital literacy skills for students. This decision aims to build awareness for students so that they able to process information by understanding messages and communicating effectively with others. Digital literacy consists of the ability to use technological devices, socialize, think critically, creatively and instinctively (Shafeeq. C.P, 2013). This ability is expected to train students so that they have collaborated, communicated skills, have ethics, understand the right benefit of technology in achieving learning objectives. Therefore, digital literacy leads to every individual having a critical and creative mindset (Effendy, 2017).

The availability of information through the mobile learning based edugame can be done by utilizing the features by learning activities that playing a game. Students were expected to be able to process information through the media, then they could look for various sources related to the material. Students were allowed to collaborate with their teammates so that they could verify the information in a team and then they can share it through social media. Learning activities could implement not only in the classroom but also anytime and anywhere. Edugame has evaluation features, such as tests so that students could examine their understanding of the material. The objectives of this research are 1) 
develop mobile learning (theme: take a breath), 2) test the effectiveness of mobile learning (take a breath) in improving digital literacy, 3) test the feasibility of mobile learning.

\section{METHODS}

This research was conducted using the research and development method; a type of research that obtains quantitative and qualitative data (mixed method). This current research aimed to produce products in the form of edugame based on mobile learning through a theoretical and practical testing process. The development model used was the ADDIE model (analysis, design, development, implementation, evaluation).

The product developed was a mobile learning-based edugame conducted through a group student trial through a validation process from material experts and media experts. The validation stage carried out by material and media experts were obtained in the form of assessment data through questionnaires. The assessment aspects used for media validation were aspects of design or appearance which include attraction or opening, the sharpness of the image, accuracy in the use of colors, arrangement or arrangement of layouts, sound quality, and consistency of the use of buttons. Furthermore, the programming aspects include the speed of opening the media/loading, ease of operating the media, clarity of instructions/instructions for use, and attracting students' curiosity.

Product trials were carried out by applying the game media to take a breath in the learning process. In the product trial process, it was carried out using the one group PreTest and Post-Test design. The subjects tested in this study were high school students of class XI-MIPA in the odd semester of the 2019/2020 school year. The trial subjects in this research and development were 30 people. The implementation of mobile learning based edugame is tested in real conditions with a wider subject. Researchers collected data in senior high school by selecting 2 test groups (purposive sampling), namely 1 experimental group and 1 control group.

The assessment of student digital literacy consists of four indicators, namely: 1) smart user, 2) sharing, 3) critical reading, and 4) socialization (Jing, 2016). The main instrument used to measure digital literacy is the student response questionnaire. Instruments in the form of observations and tests as supporting data from digital literacy and learning outcomes (cognitive aspect). Scores of student responses were carried out in the analysis process using descriptive and analytic statistics. First, calculating the grade point average of students then the digital literacy category of students is based on the categories presented in Table 1 (Mardapi, 2008). Furthermore, digital literacy data is analyzed using the t-test to obtain a significant value. Data were analyzed with the requirement test, which is the sample from the population was normally distributed and the group used had a homogeneous variance (Creswell, 2012).

Table 1. The Categories of Digital Literacy Skill

\begin{tabular}{|c|c|}
\hline Scores & Categories \\
\hline$x>3,33$ & very good \\
\hline $3,33>x>2,5$ & good \\
\hline $2,5>x>1,67$ & enough \\
\hline$x<1,67$ & low \\
\hline
\end{tabular}

Gain scores were used to analyze the increase in students' cognitive abilities then categorized based on the N-Gain formula. Normalized score gain categories are shown in the following formula 1 (Hake, 2017). The formula of the gain score used in this study was as followed. 


$\begin{aligned} & \text { Gain score }= \frac{\text { posttest } \text { score }- \text { pretest score }}{\text { maximum } \text { score }- \text { pretest score }} \\ & \text { Table 2. Gain Score Interval } \\ &$\[ \begin{array}{|l|l|}\hline \text { N-Gain Score } & \text { Criteria } \\ \hline \mathrm{g}>0,7 & \text { High } \\ \hline 0,3 \leq \mathrm{g}<0,7 & \text { Enough } \\ \hline \mathrm{g}<0,3 & \text { Low } \\ \hline\end{array} \]$\end{aligned}$

The feasibility of the product is determined through the acquisition of a good category. If the results of the assessment by experts and students show the final results in the good category, the media is suitable for use.

\section{RESULTS \& DISCUSSION}

\section{Results}

Based on research that have been done regarding the development of mobile learning-based edugame on the respiratory system material, product development is carried out at the stages, starting from the analysis of student needs, analysis of student characteristics, and curriculum analysis. At the stage of analysis of the needs of students obtained interviews with the teacher that the media used are still oriented towards authentic media, namely posters, charters, and torso. The media is also still within certain material limits, so it still does not reach other materials. This can have an impact on the lack of student activity space in building their knowledge individually or collaboratively.

The analysis phase of student characteristics was carried out with interviews related to students' digital literacy skills in biology subjects. In general, students of class XI IPA were still not accustomed to verifying information and data obtained from online sources. This condition tends students to immediately receive information without ensuring the validity of the information. Based on the results of curriculum analysis conducted by researchers, school adopts the curriculum 2013 which is implemented with a moving class. The method of moving class was done so that the teacher on the subject can prepare learning activities optimally.

The third stage was the development of edugame media products. Development of Edugame based on the analysis of students' characteristics and needs. Edugame media developed has the characteristics of challenges in the game in the form of questions that are presented with various levels of ability. This means that students can proceed to the next level if they can complete each level according to the rules in the edugame.

Development in the fourth stage was expert validation and revision. Validation was carried out based on the material expert assessment instrument, media, and student response questionnaire to determine the level of readability of students against edugame media. Media validation was carried out by direct edugame media assessment by material experts (Zen Ladestam, M.Sc. from LIPI researchers) and media experts (Arum Adita, M.Pd, lecturer and researcher from UMP, Purwokerto) and questionnaire responses from class XI IPA students. Based on the validation carried out by experts, especially the matter of the respiratory system in humans, media experts and student responses obtained an average percentage based on the provisions of the assessment criteria. A summary of the results of edugame media validation is shown in table 1 to table 3 . 

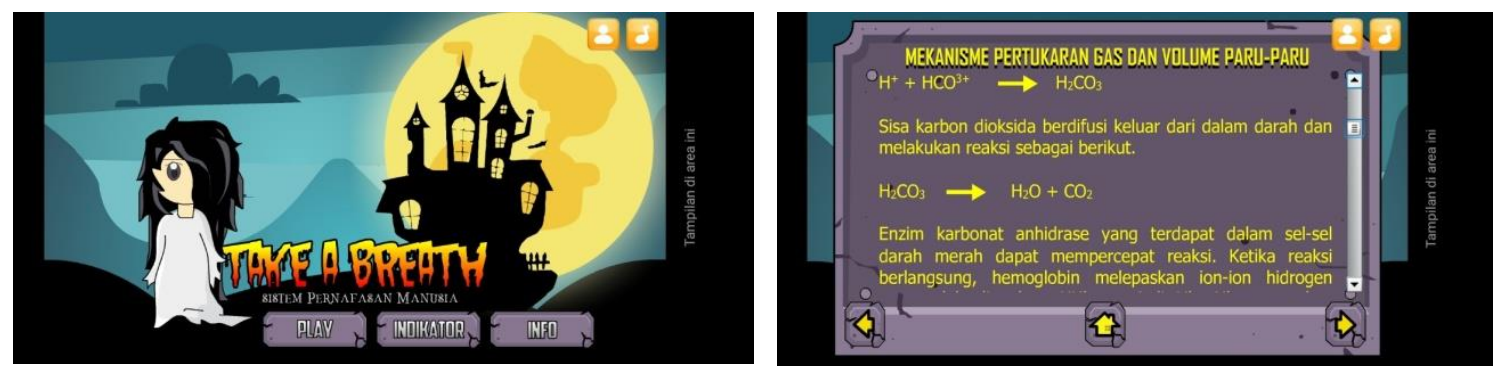

Figure 1. The Display of the introduction of mobile learning and content
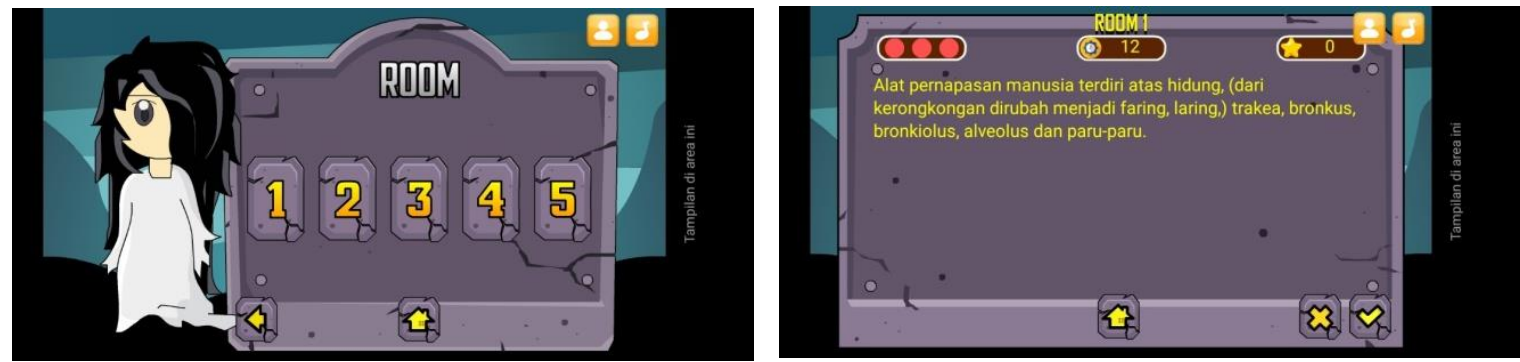

Figure 2. The Display of Game Level

Table 1. Summary of Edugame Media Validation by Content Expert

\begin{tabular}{lcc}
\hline \multicolumn{1}{c}{ Validated aspects } & Percentage (\%) & Criteria \\
\hline $\begin{array}{l}\text { The suitability of the material with } \\
\text { the specified competencies }\end{array}$ & $81,25 \%$ & Valid \\
$\begin{array}{l}\text { The accuracy and correctness of the } \\
\text { material }\end{array}$ & $83,33 \%$ & Valid \\
$\begin{array}{l}\text { Learning support material } \\
\text { Average }\end{array}$ & $82,14 \%$ & Valid \\
\hline
\end{tabular}

Table 2. Summary of Edugame Media Validation by Media Experts

\begin{tabular}{lcl}
\hline \multicolumn{1}{c}{ Aspek yang divalidasi } & Persentase (\%) & \multicolumn{1}{c}{ Kriteria } \\
\hline Presentation technique & $83,33 \%$ & Valid \\
Feasibility of presentation & $81,25 \%$ & Valid \\
Feasibility of media graphics & $87,5 \%$ & Very valid \\
Average & $84,02 \%$ & Valid with slight revisions \\
\hline
\end{tabular}

Comments and suggestions from each validator were used by researchers as reference material to make improvements to the developed edugame media. Comments and suggestions from each validator have been completed by researchers as a form of refinement of edugame media. Comments and suggestions from each expert judgement (content and media) and student response are presented as follows:

Table 3. Comment and Content suggestions from Content Expert

\begin{tabular}{ll}
\hline Indicator of assessment & Suggestion \\
\hline Image illustration & $\begin{array}{l}\text { Please look for images that are more } \\
\text { detailed and have a maximum brightness } \\
\text { level. } \\
\text { Correct the writing of mistyped words. }\end{array}$ \\
Writing structure &
\end{tabular}


Tabel 4. Comment and Content suggestions from Media Expert

\begin{tabular}{cl}
\hline \multicolumn{1}{c}{ Indicators } & \multicolumn{1}{c}{ Comments } \\
\hline Content typography & $\begin{array}{l}\text { The layout of images with writing to be } \\
\text { more proportionate and tidy. }\end{array}$ \\
\hline
\end{tabular}

The field trial phase was carried out limited to one class with a total of 30 students. The trial aims to determine the level of readability and the effect of the use of Edugame media on the digital literacy skills of students. The field trial consisted of 2 stages, namely: a readability test and a media trial. Readability test aims to enable students to assess Edugame media based on predetermined indicators. The results of the level and readability test and the effect of Edugame media on increasing digital literacy are presented successively as follows:

Table 5. Summary of the results of student questionnaire responses to edugame media

\begin{tabular}{lcc}
\hline Indicator of assessment & Score average & Categori \\
\hline Programming aspect & $81,25 \%$ & Valid \\
Content aspect & $84,75 \%$ & Valid \\
Display aspect & $77,75 \%$ & Valid \\
Average & $81,25 \%$ & Valid with slight revisions \\
\hline
\end{tabular}

Data strongly indicates that the students were significantly feel comfortable in using edugame. Edugame provides concrete empirical support for the biological case especially in respiratory system. Indeed, accessibility feature make it an ideal learning tool.

Table 6. Prerequisite tests

\begin{tabular}{|c|c|c|c|c|c|}
\hline \multirow[t]{2}{*}{ Type of test } & \multicolumn{3}{|c|}{ Kolmogorov-Smirnov } & $\alpha$ & Summary \\
\hline & Variable & $\mathrm{df}$ & Sig. & & \\
\hline \multirow[t]{2}{*}{ Normality } & Cognitive & 40 & 0,200 & 0,05 & $\begin{array}{l}\text { Data is normally } \\
\text { distributed }\end{array}$ \\
\hline & Digital literacy & 40 & 0,054 & 0,05 & $\begin{array}{l}\text { Data is normally } \\
\text { distributed }\end{array}$ \\
\hline Type of test & \multicolumn{3}{|c|}{ Levene test } & $\alpha$ & Summary \\
\hline Homogeneity & $\begin{array}{c}\text { Variable } \\
\text { Cognitive }+ \text { digital } \\
\text { literacy }\end{array}$ & $\begin{array}{l}\mathrm{df} \\
40\end{array}$ & $\begin{array}{l}\text { Sig. } \\
0,128\end{array}$ & 0,05 & Homogeneous data \\
\hline
\end{tabular}

Based on the prerequisite test results showed that the normality test using Kolmogorov-Smirnov with the acquisition of results that cognitive ability has a significance value greater than $\alpha$ (Sig. $>\alpha)$ then the data is normally distributed. Furthermore, digital literacy is $0.054>0.05$ so the data is normally distributed. Homogeneity test using the Levene test shows that the value is $0.128>0.05$ (Sig. $>\alpha$ ) so the data is homogeneous.

Table 7. Hypothesis Testing

\begin{tabular}{clcccc}
\hline Type of test & \multicolumn{3}{c}{ One-Sample Test } & $\alpha$ & Summary \\
\cline { 2 - 3 } t-test & $\begin{array}{l}\text { Variable } \\
\text { Cognitive + digital }\end{array}$ & $\begin{array}{c}\mathrm{df} \\
\text { literacy }\end{array}$ & $\begin{array}{l}\text { 0,000 Sig. } \\
\text { tailed) }\end{array}$ & 0,05 & $\begin{array}{l}\text { Hypothesis } \\
\text { accepted }\end{array}$ \\
\hline
\end{tabular}


Hypothesis test calculations are performed using SPSS 16.00 with the acquisition of a value of $0,000<0.05$ which means that there is a significant influence on cognitive and digital literacy through the implementation of Edugame media on the material of the human respiratory system.

Table 8. Summary of Digital Literacy Student Assessment Results

\begin{tabular}{lcc}
\hline \multicolumn{1}{c}{ Indicator } & Score average & Category \\
\hline Smart user & 3,92 & Very good \\
Sharing & 3,17 & Good \\
Critical reading & 3,37 & Very good \\
Socialization & 3,22 & Good \\
Average & 3,42 & Very Good \\
\hline
\end{tabular}

Table 9. Calculation results for the N-Gain Score test

\begin{tabular}{lc}
\multicolumn{1}{c}{$\begin{array}{c}\text { Percentage (\%) } \\
\text { N-Gain }\end{array}$} & $\begin{array}{c}\text { Percentage (\%) } \\
\text { amount of students }\end{array}$ \\
\hline High & $27,5 \%$ \\
Medium & $70 \%$ \\
Low & $2,5 \%$ \\
N-Gain Average & $55 \%$ \\
\hline
\end{tabular}

Based on the data in table 9. 11 students have a high increase, 28 students with a moderate increase in categories, and 1 student with a low increase. The average N-Gain with a gain of 55\% means an increase in students' cognitive abilities is in the medium category. This shows that the influence of the use of edugame media is quite influential in improving students' cognitive abilities at a moderate level.

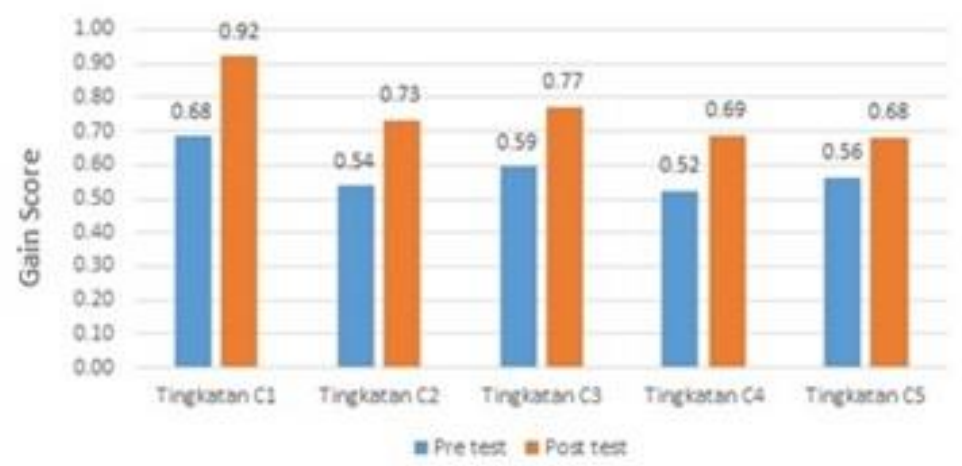

Figure 3. Recapitulation of Students' Cognitive Abilities

Based on the results (Figure 1) on the pretest and showed a significant gain score, especially at the $\mathrm{C} 1$ level with an increase of 0.92 . Furthermore, data of higher-order thinking $(\mathrm{C} 4, \mathrm{C} 5)$ showed a good improvement. This is caused that in learning activities students are supported through interesting media and supported activities that lead to the ability to think to solve problems. 


\section{Discussion}

Implementation of learning using Edugame, students feel the media is useful in helping to understand the concept of biological material, has challenges in learning and can adjust to the time allocation provided. Students who study online will be able to choose their learning patterns in a variety of ways because they have the power of flexibility, comfort, and accessibility (Heirdsfield et al., 2007; Stone, 2012). This condition will lead to the pattern of independent learning and gives the teacher a perception that student learning patterns will be easily controlled. Therefore the use of smartphones in learning can be used to improve communication and management in the administration of education, for example, tracking student activities and stimulating students in learning (Traxler \& Vosloo, 2014).

Analysis of the effectiveness of Edugame on digital literacy on the aspects of smart users and practicing critical reading skills has a very good category acquisition. This shows that the use of the Edugame is beneficial for students and able to accommodate student needs. Students can validate the information directly as they receive. When the process of validation is conducted, students will examine the suitable information in the context of students' logic. In this case, the ability of critical reading correlates with the ability of smart users which can capture information, especially on biological material. They also can appreciate every opportunity to learn and discuss findings that are still not appropriate online and reflect through these tools. This condition becomes their learning material to validate their views about the concept of the topic (Flavell et al., 2019; Wingo et al., 2017). This condition becomes their learning material to validate their views about the concept of biology.

On the other hand, the average value of digital literacy based on $\mathrm{N}$-Gain showed that the increase in students occurred after using Edugame with the result of $27.5 \%$ in the high category, $70 \%$ in the medium category and $2.5 \%$ in the low category. Activities in instructional media stimulate students to be able to produce ideas from various points of view (Shafeeq. C.P, 2013). Furthermore, the teacher also has a role to facilitate their students to be able to analyze information during using the media until they can provide strong arguments based on students' knowledge. This is also supported by the Hypothesis test using the t-test, that the use of the Edugame media has a significant impact on digital literacy and cognitive. In summary, edugame media provide very interesting possibilities for student follow simulation about biology concepts. They can be highly active because they can explore material, animation, literature review, and test exercise as game which is given in the media.

The implementation of the Edugame media can enrich students from the content exploration aspect and enable students to practice independently based on the media. Students can also create their learning strategies according to needs and abilities. Importantly, this media also enables students to develop and refine digital literacy and cognitive ability that is useful for their lives and future (Shemberger \& Wright, 2014). Therefore, technology needs to be utilized and linked between content and subjects who study and connect to information to be able to solve problems. Finally, this study confirms that giving students facilities to learn using technology packaged in games and connected to the internet seems to be very important in improving digital literacy and cognitive. In this case, of course, the teacher's role is very necessary for accompany students to know how and when they use the media optimally. 


\section{CONCLUSION}

The results of this study indicate that mobile learning based Edugame is effective to implement in the respiration system material. This can be evident from the results of validation from content and media experts that this media is a good category. The response of students states that media comfortable in learning biology. The use of mobile learning based edugame can improve the digital literacy of the student who especially in critical reading and students as smart users. Furthermore, it also improves the cognitive aspect, for example improving the students' high order thinking skills. Mobile learning-based edugame can also be a guide for future researchers. In future studies, the product can be developed in different designs and features such as tutorial videos.

\section{REFERENCES}

Asrizal, Amran, A., Ananda, A., Festiyed, F., \& Sumarmin, R. (2018). The development of integrated science instructional materials to improve students' digital literacy in scientific approach. Jurnal Pendidikan IPA Indonesia, 7(4), 442-450. https://doi.org/10.15294/jpii.v7i4.13613

Creswell, J. W. (2012). Educational Research: Planning, Conducting, and Evaluating Quantitative and Qualitative Research. Boston.

Dwiyono. (2017). Game. E-Journal Universitas Negeri Yogyakarta, 7(2), 343-351.

Effendy, M. (2017). Gerakan Literasi Nasional. Literasi Digital Gerakan Literasi Nasional, $1-34$.

Eliana, E. D. S., Senam, S., Wilujeng, I., \& Jumadi, J. (2016). The effectiveness of projectbased e-learning to improve ict literacy. Jurnal Pendidi-Kan IPA Indonesia, 5(1), 5155.

Flavell, H., Harris, C., Price, C., Logan, E., \& Peterson, S. (2019). Empowering academics to be adaptive with eLearning technologies: An exploratory case study. Australasian Journal of Educational Technology, 35(1), 1-15. https://doi.org/10.14742/ajet2990

Hague, C., \& Payton, S. (2010). Digital literacy across the curriculum Key to themes: A Futurelab handbook. United Kingdom.

Hake, R. R. (2017). Design-based research in physics education: A review. Semanticscholar, 1(1). https://doi.org/http://doi.org/10.4324/9781315759593-42

Heirdsfield, A., Davis, J., Lennox, S., Walker, S., \& Zhang, W. (2007). Online learning environments: What early childhood teacher education students say. Journal of Early Childhood Teacher Education, 28(2), 115-126. https://doi.org/https://doi.org/10.1080/10901020701366699

Ibrahim, N., \& Ishartiwi, I. (2017). Pengembangan media pembelajaran mobile learning berbasis android mata pelajaran IPA untuk siswa SMP. Jurnal Ilmiah Kependidikan, 8(1). https://doi.org/10.24176/re.v8i1.1792

Jing, L. I. U. (2016). Multiliteracies in College English Pedagogy. Sino-US English Teaching, 13(8).

Kutluca, T. (2010). Investigation of teachers' computer usage profiles and attitudes toward computers. International Online Journal of Education Sciences, 2(1), 81-97.

Lailiyah, S. (2018). Pentingnya membangun pendidikan sains. Jurnal Kajian Pendidikan Sains, IV(2), 178-187.

Ljungkvist, P., \& Mozelius, P. (2012). Educational games for self learning in introductory programming courses - A straightforward design approach with progression mechanisms. Proceedings of the European Conference on Games-Based Learning, 285-294. 
Mardapi, D. (2008). An analysis of method of cheating on large test scale. Jurnal Penelitian Dan Evaluasi Pendidikan, 122.

Prasetyo, Y. A., \& Djauhar, A. (2017). Mendorong profesionalisme pers melalui verifikasi perusahaan pers. Jurnal Dewan Pers, 11-29.

Ramansyah, W. (2015). Pengembangan education game (edugame) berbasis android pada mata pelajaran bahasa Inggris Untuk Peserta Didik Sekolah Dasar. Jurnal Ilmiaah Edutic, 2, 1-9.

Shafeeq. C.P. (2013). Redefining Education in The World of ICTs. International Journal of English and Education, 2(1), 284-288.

Shemberger, M., \& Wright, L. (2014). Exploring the use of social media as a digital study guide. Journal of Interdisciplinary Studies in Education, 3(1), 60-75.

Shroff, R. H., Ting, F. S. T., \& Lam, W. H. (2019). Development and validation of an instrument to measure students' perceptions of technology-enabled active learning. Australasian Journal of Educational Technology, 35(4), 109-127. https://doi.org/10.14742/ajet.4472

Stone, C. (2012). Engaging students across distance and place. Journal of the Australian and New Zealand Student Services Association. Retrieved from Journal of the Australian and New Zealand Student Services Association website: https://www.anzssa.com/public/94/files/JANZSSA editions/JANZSSA April 2012_Number_39.pdf

Talan, T. (2020). The effect of mobile learning on learning performance: A meta-analysis study. Educational Sciences: Theory \& Practice, 20(1), 79-103. https://doi.org/10.12738/jestp.2020.1.006

Taufiq, M., Dewi, N. R., \& Widiyatmoko, A. (2014). Pengembangan media pembelajaran ipa ter-padu berkarakter peduli lingkungan tema "konservasi" berpendekatan scienceedutain-ment. Jurnal Pendidikan IPA Indonesia, 3(2).

Traxler, J., \& Vosloo, S. (2014). Introduction: The prospects for mobile learning. Prospects, 44(1), 13-28. https://doi.org/https://doi.10.1007/s11125-014-9296-z

Wingo, N. ., Ivankova, N. V, \& Moss, J. A. (2017). Faculty perceptions about online teaching exploring the literature using the technology acceptance model as an organizing framework. Online Learning, 21(1), 15-35. https://doi.org/https://doi.org/10.24059/olj.v21i1.761

Zhang, Y., \& Zuo, L. (2019). College English teaching status and individualized teaching design in the context of mobile learning. International Journal of Emerging Technologies in Learning, 14(12), 85-96. https://doi.org/10.3991/ijet.v14i12.10704 